\title{
Anxiety Towards the English Language in Relation to Academic Performance of Grade 11 Students of University of Bohol
}

\author{
RODEN A. NICOSIA \\ ranicosia@universityofbohol.edu.ph \\ https://orcid.org/0000-0001-9998-8909 \\ CHARITY J. ESMERO \\ cjesmero@universityofbohol.edu.ph \\ https://orcid.org/0000-0001-7591-6046
}

\begin{abstract}
Language anxiety is a complex psychological construct described as an apprehension that occurs when a language student performs a second or foreign language. Academic performance is referred to as the grades of the students in the English subject. The study aimed to determine the English Anxiety in relation to academic performance of the respondents. This study used a descriptive survey method of assessing the level of English language anxiety and the academic performance of the students in English. Documentary analysis was used for academic performance in the English subject of the School Year, 2017-2018. The result revealed that students at the University of Bohol- Senior High School have a low level of English Anxiety. This result showed that the language anxiety significantly affected the academic performance of the students in which the higher the English language Level of Anxiety, the lesser is the academic performance of the students. Teachers should provide a healthy environment and conducive learning atmosphere. The language instructor should have a stringent-free approach and friendly personality so that the students won't be frightened in making a mistake in the language class. It is also vital that
\end{abstract}


students should be encouraged to speak up and let them practice both the esteem and English language proficiency. Above all, there should be an integration between the English curriculum and extra-curricular activities to motivate students to use it for further competitions. Extra-curricular activities should be a vehicle for the enhancement and development of student's skill.

Keywords: Anxiety, academic performance, descriptive-survey method, documentary analysis, Bohol, Philippines

\section{INTRODUCTION}

The need for mastery in academic English, both oral and written in secondary and higher education is becoming more vital and significant in the 21st century. In modern trends, the English language dominates in the different fields of profession, aside from being the language taught in school and the one preferably used in the community.

Presently, the English language is said to be the most critical language. In the ASEAN, it is the working and sole official language of the organization (Kirkpatrick, 2008). As a developing country in the ASEAN, the Philippines encouraged its human resources to master the English language to become competent and effective in the global market.

A dearth of research is observable despite the deploring quality of the English language of the learners in the Philippines. English teachers, in general, have observed that their senior high school students cannot speak the language fluently. Further, they could not spell words correctly, nor punctuate sentences properly. Using the English language as the medium of communication instills in them the feelings of uneasiness, frustration, self-doubt, insecurity, or apprehension.

Anxiety, according to Spielberger (1966), is the "subjective, consciously perceived feelings of apprehension and tension, accompanied by or associated with activation or arousal of the autonomic nervous system." Horwitz, Horwitz, and Cope (1986) characterize anxiety as "high feelings of self- consciousness, fear of making mistakes, and a desire to be perfect when speaking." When incorporated into language learning, anxiety is the apprehension that occurs when a language student performs a second or foreign language (Gardner \& Maclntyre, 1993). 
Language learning anxiety is a well-researched subject in the North American, European, Canadian, and Asian setting- (Hurd, 2007; Kim, 2009; Liu \& Jackson, 2008; Matsuda \& Gobel, 2004; Satar \& Özdener, 2008; Yan \& Horwitz, 2008; Kao \& Craigie, 2010; Trang, T. T. T., Moni, K., \& Baldauf, R. B. 2012; Cui, 2011; Cebreros, 2003; Pappamihiel, 2002)—but in the Central Visayan region of the Philippines, newly adopting the $\mathrm{K}+12$ senior high school program with a completely different learning context, it seems to be a neglected, virtually unresearched area. The researcher adheres that the existence of differences in gender, age, and strand in the senior high school program provides a fertile avenue for teaching and research (WISELI, 2010).

With these impetuses, the researcher aims to investigate the English language anxiety of Grade 11 senior high school students from the University of Bohol. The researcher believes that in exploring students' English anxiety, a relevant idea may prevail, which would possibly explain why English is an anxiety-provoking subject among learners. There is a need to associate their profile in terms of sex, age, and senior high school strand to their anxieties in English. It is the prime objective of the researcher to find out the relationship of English language anxiety vis-avis performance in the English classes of Grade 11 senior high school students in University of Bohol located at Tagbilaran City, Bohol.

Acquiring skills in learning the English language is affected by many factors. Physical, social, and emotional influences may substantially affect the success of obtaining a second language. The study was anchored on the succeeding theories.

Second Language Acquisition Theory. This theory, proposed by Krashen (1987) states that there are five main hypotheses which composed this theory.

First is the Acquisition-Learning Hypothesis, which states that adults have two ways of developing competence in the second language; 1) acquisition or the subconscious learning and 2) learning or the conscious learning. The former is similar to the process that a child undergoes upon acquiring his first language. This process requires a process of experiencing natural communication or conversation to gain knowledge of the language. The latter is a product from formal schooling instruction that involves education on the language such as learning semantics and syntax. Krashen believes that acquisition or learning the language unconsciously is much more effective and valuable than learning the 
language in formal education.

Second is the Natural Order Hypothesis. It states that acquiring grammatical structures follows a predictable order. It further explains that the order depends on the child's background, age, and exposure to the environment.

The third is the Monitor Hypothesis. It focuses primarily on learning. While the child acquires language, frequent monitor through formal education should be reinforced for successful language acquisition.

Fourth is the Input Hypothesis, which dictates that speaking fluency happens over time. When the child is exposed to the language beyond his level, acquisition of language will occur. This hypothesis suggests that when a learner is learning in his early stages, the beginnings of letters and sounds, the acquisition is far at par.

The fifth is the Affective Filter Hypothesis, which explains that low affective filter contributes to good learning. This concept means that the affective variables such as confidence, motivation, and anxiety affect the acquisition of the second language. This theory dictates that learners who have a high level of confidence, motivation, and self-esteem, and a low level of anxiety can do better in the acquisition of the second language.

Foreign Language Anxiety (FLA) Theory. According to Horwitz, Horwitz, and Cope (1986), FLA is a complex construct of self-perceptions, beliefs, and behaviors related to classroom language learning arising from the uniqueness of the language learning process. They have drawn three related performance anxieties, namely, communication apprehension, test anxiety, and fear of negative evaluation. To measure such, they formulated FLCAS-33-item test, which measures the student's beliefs, perceptions, and attitudes towards language anxiety. The results showed that many students experience a significant level of foreign language anxiety in response to 19 of 33 items. Thus, anxious students are evident in a foreign language class.

Zone of Proximal Development (Zo-ped). Vygotsky (1978) defined Zo-ped as "the distance between the actual developmental level as determined by independent problem solving and the level of potential development as determined through problem-solving under adult guidance, or in collaboration with more capable peers" (Vygotsky 1978). This theory means that the activities a child can do independently are the measurement of his actual development. Zone of proximal development measures the activities where the child is not yet fully matured needs collaboration among 
peers and adults. Vygotsky, in his theory, views interaction with peers as an effective medium to develop skills and strategies. He further suggests that cooperative learning activities between a less competent child and skillful peers are a must within a zone of proximal development. Through ZPD, the child's confidence will be boosted to do tasks such as learning the foreign language. This theory implies that for a child to develop his skills and potentials, an excellent way to maximize and effectively learn would be collaborative work. It happens when a skillful peer would be helpful in learning skills where one does not entirely master.

Language acquisition could be best mastered not only with one's practice but also with the influence surrounding the individual. ZPD supports the idea that in learning the second language, collaborative work should be utilized to maximize learning. A well-guided practice promotes a well-developed individual.

Some other theorists believe that other factors are affecting second language acquisition.

Language anxiety is a complex psychological construct described as an apprehension that occurs when a language student performs a second or foreign language (Gardner \& Maclntyre, 1993). Maclntyre (1999) further expounds that it is not just a common fear in learning but rather a worrisome reaction when studying a second language. $\mathrm{Na}$ (2007) also considers anxiety as one of the most important affective factors that influence second language learning.

Language anxiety has been considered as one of the contributing factor in learning a foreign language because anxiety can impede the learning process (Hilleson, 1996; Horwitz, Horwitz \& Cope, 1986; Kaya, 1995; Tsui, 1996; Young, 1991). When students experience high anxiety levels, concentration towards learning is obstructed resulting to failure in performing a task in English classes ( Horwitz, Horwitz \& Cope, 1986; Maclntyre \& Gardner 1993; Maclntyre, Noels \& Clement, 1997; Samimy \& Rardin, 1994). Some people see the anxiety of a language student as an excuse for not participating in class or a guise to hide a lack of study. But anxiety may be the "linchpin of the entire affective reaction to language learning." (Maclntyre, 1999).

Anxiety and Language Learning. According to Horwirz, Horwitz, and Cope (1986) and Casado \& Dereshiwsky (2001), foreign language anxiety affects performance evaluation in the social and academic context. They cited three related performance anxieties, namely communication 
apprehension, fear of negative evaluation, and a general feeling of anxiety towards a foreign language. Communication apprehension is the fear and anxiety in communicating with people. Difficulty in speaking in public, listening or learning a spoken utterance are all manifestations of communication apprehension. The learners' knowledge that they will have difficulty understanding others and making themselves understood are the sources of this anxiety. Learners suffering from communication apprehension choose to keep silent in their English classes. The second component is the fear of negative evaluation. Learners feel apprehension about other people's evaluation. This second component may also include avoidance of evaluative situations and the expectations that others might evaluate them negatively. Student's fear inside the English classroom because of learning activities, teacher's methodology, and peer pressure contributes to language learners' anxieties. The third component, which is a general feeling of anxiety towards a foreign language, is the "feelings of apprehension related to other sensations of apprehension akin but not intrinsically linked to communication or fear of negative evaluation" (Casado \& Dereshiwsky, 2001). Foreign language anxiety is a complex of self-perceptions, behaviors, attitudes, beliefs, and feelings arising from the language learning process (Horwirz, Horwitz, and Cope, 1986).

A number of studies have ascertained that anxiety has a negative impact on the language learner and was said to be one of the strongest measurement of success in language learning (Mclntrye, 1999). Understanding the learner's apprehensions towards the target language is indeed crucial in language teaching and learning.

Several research studies have explored the relationship of Language anxiety to language learning. The most influential study is by Horwitz, Horwitz, and Cope (1986) in which they proposed the Foreign Language Classroom Anxiety Scale. This scale became the basis of almost all foreign/ second language anxiety studies. The results of the study demonstrated that Foreign Language Anxiety was responsible for students' negative emotional reactions to language learning. Adults usually view themselves as reasonably intelligent, socially-adept individuals, sensitive to different socio-cultural norms and mores. When communicating using a foreign language, the individual's communication attempts is evaluated according to uncertain linguistic and socio-cultural standards. "Because complex and non-spontaneous mental operations are required to communicate, any performance in the second language is likely to challenge an individual's 
self-concept as a competent communicator and lead to reticence, selfconsciousness, fear, or even panic" (p. 128).

A study of Saidi (2015) involved 50 students from the whole population of the first year LMD students of English at Mohammed Khider University of Biskra, Algeria. This study stated that there is a significant relationship between foreign language anxiety and performance. The participants of this study said that speaking a foreign language makes them feel more anxious. This anxiety is generated by factors like communication apprehension, test anxiety, fear of negative evaluation, lack of motivation, negative self-perceptions, speaking activities, competitiveness, lack of self-confidence, and fear of making mistakes. Moreover, foreign language anxiety has a big effect on the three stages of learning, namely, input, process, and output. This anxiety hinders the development of students acquisition of the English Language.

Another study focusing on language anxiety was done by Von Wörde's (2003). The research listed factors which may contribute to language anxiety in learning English and the ways to reduce them. The findings revealed several negative experiences from the students, and mentioned how anxiety is translated to frustration and anger. The reason for this is anxiety was often confused with the words nervousness and frustration. However, most of the participants feel better knowing that they are not alone intheir anxiety and that others also experience the same way.

Another study also was conducted by Williams and Andrade (2008) in which they examined the anxiety among 243 randomly selected Japanese students in 31 conversational English classes in six universities in Japan. Their goal was to analyze situations that provoked language anxiety, its cause, and the ability of the students to cope with it. The findings of the study indicated that most Japanese EFL students' anxiety is associated with output-related tasks, such as speaking in front of the class. The study's findings also indicated that the cause of anxiety is apprehension towards the teacher, the fear of the negative evaluation, and the inability to control anxiety.

Chan and Wu (2004) examined the language anxiety among 601 fifth grade students from 205 elementary schools in Taipei County. Results showed that, first, there is no doubt of the existence of foreign language anxiety among the children. The level of language anxiety is also negatively correlated with learning achievement. Second, the sources of language anxiety included low proficiency, anxious personality, pressure 
both from classmates and parents, and fear of negative evaluation. Third, results also indicated that there are five anxiety-provoking situations: tests, speaking in front of others, spelling, incomprehensible input, and speaking to native speakers. Lastly, this research study indicates that the teachers' knowledge of the existence of anxiety is not enough to solve the problem of foreign language anxiety.

This study intended to determine the level of anxiety towards the English language and its relationship to academic performance among the Grade 11 Senior High School students of the University of Bohol for the school year 2017-2018. The findings will serve as the basis for recommendations.

Specifically, it intended to address the following questions:

1. What is the profile of the respondents in terms of:

1.1 sex;

1.2 age;

1.3 strand in the Senior High School program?

2. What is the level of English language anxiety among the four groups of respondents?

3. What is the level of academic performance among the four groups of respondents using the grade point average in English?

4. Is there a significant degree of correlation between the levels of English Anxiety and academic performance of the Grade 11 students?

5. Is there a significant degree of correlation between age and the level of English Anxiety?

6. Is there a significant degree of variance on the English Language Anxiety and academic performance when the respondents are grouped according to strand?

7. Based on the findings, what lesson design may be formulated?

The study has the following null hypotheses:

1. There is no significant degree of relationship between the male and female respondents as to its:

1.1 English language anxiety; and

1.2 academic performance.

2. There is no significant degree of correlation between English language anxiety and Academic Performance.

3. There is no significant degree of variance on the level of English Anxiety and Academic Performance. 


\section{RESEARCH METHODOLOGY}

To achieve the purpose of the study, the researchers employed the descriptive survey method making use of a questionnaire patterned after a standardized tool measuring the student's English Language Anxiety. The research used the purposive sampling technique. There were 267 randomly selected Grade 11 senior high school student-respondents who were officially enrolled for the School Year 2017-2018. Furthermore, the documentary analysis of the students' grade point average in English was used.

The conduct of the study was at the University of Bohol, Senior High School Department in Tagbilaran City. It is a private senior high school with a population of 1,300 students headed by a Principal and supported by 25 teachers. The study used a questionnaire patterned after a standard tool called, "Foreign Language Classroom Anxiety Scale (FLCAS)" developed by Horwitz, Horwitz, and Cope. The grades of the students were calculated with 50 percent performance task, 25 percent written test, and 25 percent from the major examination. The researcher gathered the profiles and the Preliminary grades of the students from the different sections. The study used frequency, percentages, weighted mean, Chi-Square, T-Test (uncorrelated), and Pearson $r$.

\section{RESULTS AND DISCUSSION}

Based on the data analyzed, the following findings were exposed:

On Profile of Grade 11 students. Among the 267 participants of the study, there were more females (149) compared to males (118). Moreover, more participants were aged 17 (178) than those who belonged to 16 (49) and 18 (40) age-bracket. More so, more participants were under General Academics Strand (GAS) with 144, Science, Technology, Engineering and Mathematics (STEM) with 63, Accounting, Business, and Management (ABM) with 43 and Humanities and Social Sciences (HUMMS) with 17 participants.

On the English Language Anxiety of the Participants. The composite mean is 2.66 with an interpretation of Low level of Anxiety.

On the Degree of Relationship Between Age and English Language Anxiety. The result showed that there is a significant degree of a negative inverse relationship between the age and the level of Anxiety of 
the participants. The study implies that age has a direct influence on the participant's level of anxiety towards the learning of the English language - the higher the age of the person, the lower the level of Anxiety.

On the Degree of Relationship Between Level of Anxiety and Academic Performance. The computation yielded an r-value of 0.21407 referred to the critical value of $0.0230 \mathrm{r}$ at $265 \mathrm{df}$, and 0.05 level of significance was found to be higher; hence, the result is significant. The null hypothesis is rejected, which explains that there was a correlation between English Anxiety and the student's academic performance. The result showed that English Anxiety of the students affects their academic performance.

On the Degree of Variance on the Level of Performance When Respondents are Grouped According to Strands. The resultant factor of 106.1965 was found to be higher than the critical value of $F$ of 2.638925 at $3 \mathrm{df}$ and at 0.05 level of significance, thus rejecting the null hypothesis. This finding indicated a significant degree of variance on the level of academic performance when respondents are grouped according to strands. STEM strand got the average academic rating of 94.25 which means that STEM performs well in terms of academic performance. HUMMS ranked second, which has an academic rating of 92.82. ABM ranked third with an academic rating of 91.09. Among the respondents, GAS strand had the lowest academic rating of 83.96.

On the Degree of Variance on the English Language Anxiety When Respondents are Grouped According to Strands. The resultant factor of 1.01440 was found lesser than the critical value of $F$ of 2.63893 at $3 \mathrm{df}$ and at 0.05 level of significance, thus accepting the null hypothesis. This finding indicated that there was an insignificant degree of variance on the English Language Anxiety when respondents are grouped according to strands. The null hypothesis implied that the majority of the participants have Low Level of Anxiety regardless of their strand.

\section{CONCLUSIONS}

Based on the findings, the researchers came up with the following conclusions:

1. Majority of the respondents were aged 17 . As for sex, the majority of the respondents were females. As for the strand, the majority were from GAS. 
2. As for the respondents on English Language level of Anxiety, the students at the University of Bohol- Senior High School had a LOW Level of English Anxiety.

3. In terms of relationship, age significantly affected language anxiety.

4. In terms of the degree of relationship, results indicated that language anxiety significantly affects the academic performance of the students. Moreover, the higher the English language Level of Anxiety, the lesser the academic performance.

5. There was a significant degree of variance on the level of academic performance when respondents are grouped according to strand. Hence, there was no significant degree of variance on the level of Anxiety when respondents are grouped into a strand. The average grade of the three strands, namely, STEM, HUMMS, and $A B M$ have Outstanding while GAS respondents resulted in a satisfactory rating. Students at the University of Bohol- Senior High School have a Low level of Anxiety regardless of the strand.

\section{RECOMMENDATIONS}

From the findings and subsequent conclusions, the researchers provided the following recommendations:

1. The students must use the English language when they do transactions in any school offices.

2. The teacher should provide a healthy environment and conducive learning atmosphere. The language instructor should have a stringent-free approach and an amicable personality so that the students will not be frightened in making mistakes in the language class. The language teacher should always accept the student's answer, whether correct or wrong and never underestimate or embarrass a student's incorrect answer. The teacher should also encourage students to speak up and let them practice both the esteem and English language proficiency.

3. Seminars, workshops, and other activities may be given to students as well as parents and guardians to further personality development. Family days, school conferences, school variety, and cultural shows may require the incorporation of such development.

4. The language teachers should understand the students' learning difference so that the students will not be upset when a 
misunderstanding occurs in their language class. The teachers should have extensive consideration and be divergent towards the student's capabilities. They need to be open-minded and learn from differences.

5. Encourage students to participate in activities that will allow them to do things by themselves and showcase them with their prowess. In that way, it does not only allow them to exercise what they can but rather exercise their confidence as well. There should be an integration between the English curriculum and extra-curricular activities to motivate students to use it for further competitions. Extra-curricular activities should be a vehicle for the enhancement and development of student's skill.

6. The determination of the English curriculum on "What to teach" may be re-visited. Furthermore, there should be strict implementation of the innovation regarding the curriculum and the "Lesson Design."

\section{REFERENCES CITED}

Casado, M. A., \& Dereshiwsky, M. I. (2001). FOREIGN LANGUAGE ANXIETY OF UNIVERSITY STUDENTS. College Student Journal, 35(4). Retrieved from https://bit.ly/2kX8j4d, (accessed last 25 June 2019).

Cebreros, A. M. O. (2003). Measuring language anxiety perceived by Spanish university students of English. Bells: Barcelona English language and literature studies, 12. Retrieved from https://bit. ly/2m7segU, (accessed last 10 July 2019).

Chan, D. Y. C., \& Wu, G. C. (2004). A study of foreign language anxiety of EFL elementary school students in Taipei County. Journal of National Taipei Teachers College, 17(2), 287-320. Retrieved from https://bit. ly/2kxJU56, (accessed last 15 May 2019).

Cui, J. (2011). Research on High School Students' English Learning Anxiety. Journal of Language Teaching \& Research, 2(4). Retrieved from https://bit.ly/2m0Qi5k, (accessed last 23 May 2019). 
Gardner, R. C., \& Maclntyre, P. D. (1993). A student's contributions to second-language learning. Part II: Affective variables. Language teaching, 26(1), 1-11. Retrieved from https://bit.ly/2mrQ2fH, (accessed last 22 June 2019).

Hilleson, M. (1996). I want to talk with them, but I don't want them to hear": An introspective study of second language anxiety in an Englishmedium school. Voices from the language classroom: Qualitative research in second language education, 248-275. Retrieved from https://bit.ly/2m2hDnA, (accessed last 13 June 2019).

Horwitz, E. K., Horwitz, M. B., \& Cope, J. (1986). Foreign language classroom anxiety. The Modern language journal, 70(2), 125-132. Retrieved from https://bit.ly/2N448k3, (accessed last 22 July 2019).

Hurd, S. (2007). Anxiety and non-anxiety in a distance language learning environment: The distance factor as a modifying influence. System, 35(4), 487-508. Retrieved from https://bit. ly/2kWRKFq, (accessed last 22 June 2019).

Kao, P. C., \& Craigie, P. (2010). Foreign language anxiety and English achievement in Taiwanese undergraduate English-major students: An empirical study. (61), 49-62. Retrieved from https://bit.ly/2kWCQPB, (accessed last 13 June 2019).

Kaya, M. (1995). The relationship of motivation, anxiety, self-confidence, and extroversion/introversion to students' active class participation in an EFL classroom in Turkey (Doctoral dissertation, Bilkent University). Retrieved from https://bit.ly/2kOgNL5, (accessed last 13 May 2019).

Kim, S. Y. (2009). Questioning the stability of foreign language classroom anxiety and motivation across different classroom contexts. Foreign Language Annals, 42(1), 138-157. Retrieved from https://bit. ly/2mtH6GO, (accessed last 17 July 2019).

Kirkpatrick, A. (2008). English as the official working language of the Association of Southeast Asian Nations (ASEAN): Features and strategies. English Today, 24(2), 27-34. Retrieved from https://bit. ly/2mq8oh6, (accessed last 21 June 2019). 
Krashen, S. D. (1987). Applications of psycholinguistic research to the classroom. Methodology in TESOL: A book of readings, 33-44. Retrieved from https://bit.ly/2kqbr8m, (accessed last 13 July 2019).

Liu, M., \& Jackson, J. (2008). An exploration of Chinese EFL learners' unwillingness to communicate and foreign language anxiety. The Modern Language Journal, 92(1), 71-86. Retrieved from https://bit. ly/2kxv8LJ, (accessed last 16 May 2019).

Maclntyre, P. D. (1999). Language anxiety: A review of the research for language teachers. Affect in foreign language and second language learning: A practical guide to creating a low-anxiety classroom atmosphere, 24, 41. Retrieved from https://bit.ly/2m0RV2W, (accessed last 16 June 2019).

Maclntyre, P. D., Noels, K. A., \& Clément, R. (1997). Biases in self $\square$ ratings of second language proficiency: The role of language anxiety. Language learning, 47(2), 265-287. Retrieved from https://bit. ly/2kY5WhA, (accessed last 16 April 2019).

Matsuda, S., \& Gobel, P. (2004). Anxiety and predictors of performance in the foreign language classroom. System, 32(1), 21-36. Retrieved from https://bit.ly/2mq97Pm, (accessed last 13 May 2019).

$\mathrm{Na}, \mathrm{Z}$. (2007). A study of high school students' English learning anxiety. The Asian EFL Journal, 9(3), 22-34. Retrieved from https://bit.ly/2m6IEXa, (accessed last 16 February 2019).

Pappamihiel, N. E. (2002). English as a second language students and English language anxiety: Issues in the mainstream classroom. Research in the Teaching of English, 327-355. Retrieved from https://bit.ly/2zE9NnB, (accessed last 18 April 2019).

Saidi, M. (2015). The Impact of Students' Anxiety on Oral Performance Case study: first year LMD students of English at Mohamed Khider University-BISKRA. Retrieved from https://bit.ly/2kqelEG, (accessed last 28 June 2019). 
Samimy, K. K., \& Rardin, J. P. (1994). Adult language learners' affective reactions to community language learning: A descriptive study. Foreign Language Annals, 27(3), 379-390. Retrieved from https://bit. ly/2IZEPmp, (accessed last 18 May 2019).

Satar, H. M., \& Özdener, N. (2008). The effects of synchronous CMC on speaking proficiency and anxiety: Text versus voice chat. The Modern Language Journal, 92(4), 595-613. Retrieved from https://bit. ly/2kWCEzR, (accessed last 23 June 2019).

Spielberger, C. D. (1966). Theory and research on anxiety. Anxiety and behavior, 1(3). Retrieved from https://bit.ly/2kzvjWU, (accessed last 21 April 2019).

Trang, T. T. T., Moni, K., \& Baldauf, R. B. (2012). Foreign language anxiety and its effects on students' determination to study English: To abandon or not to abandon?. Foreign language anxiety and its effects on students' determination to study English: To abandon or not to abandon?, 1-14. Retrieved from https://bit.ly/2kuADuB, (accessed last 18 June 2019).

Tsui, A. B. (1996). Reticence and anxiety in second language learning. Voices from the language classroom, 145-167. Retrieved from https://bit.ly/2kxHbZq, (accessed last 14 June 2019).

Von Worde, R. (2003). Students' Perspectives on Foreign Language Anxiety. Inquiry, 8(1), n1. Retrieved from https://bit.ly/2m0JGnx, (accessed last 18 June 2019).

Vygotsky, L. (1978). Interaction between learning and development. Readings on the development of children, 23(3), 34-41. Retrieved from https://bit.ly/2mmw8me, (accessed last 13 June 2019).

Williams, K. E., \& Andrade, M. R. (2008). Foreign language learning anxiety in Japanese EFL university classes: Causes, coping, and locus of control. Electronic Journal of Foreign Language Teaching, 5(2), 181191. Retrieved from https://nus.edu/2m7w1uE, (accessed last 15 July 2019). 
Yan, J. X., \& Horwitz, E. K. (2008). Learners' perceptions of how anxiety interacts with personal and instructional factors to influence their achievement in English: A qualitative analysis of EFL learners in China. Language learning, 58(1), 151-183. Retrieved from https://bit. ly/2kXndYc, (accessed last 16 July 2019).

Young, D. J. (1991). Creating a low $\square$ anxiety classroom environment: What does language anxiety research suggest?. The modern language journal, 75(4), 426-437. Retrieved from https://bit.ly/208jf8E, (accessed last 15 June 2019). 